\title{
Hydrolysis optimization and characterization study of preparing fatty acids from Jatropha curcas seed oil
}

\author{
Jumat Salimon*, Bashar Mudhaffar Abdullah and Nadia Salih
}

\begin{abstract}
Background: Fatty acids (FAs) are important as raw materials for the biotechnology industry. Existing methods of FAs production are based on chemical methods. In this study potassium hydroxide $(\mathrm{KOH})$-catalyzed reactions were utilized to hydrolysis Jatropha curcas seed oil.

Results: The parameters effect of ethanolic $\mathrm{KOH}$ concentration, reaction temperature, and reaction time to free fatty acid (FFA\%) were investigated using D-Optimal Design. Characterization of the product has been studied using Fourier transforms infrared spectroscopy (FTIR), gas chromatography (GC) and high performance liquid chromatography (HPLC). The optimum conditions for maximum FFA\% were achieved at $1.75 \mathrm{M}$ of ethanolic $\mathrm{KOH}$ concentration, $65^{\circ} \mathrm{C}$ of reaction temperature and $2.0 \mathrm{~h}$ of reaction time.
\end{abstract}

Conclusions: This study showed that ethanolic $\mathrm{KOH}$ concentration was significant variable for J. curcas seed oil hydrolysis. In a 18-point experimental design, FFA\% of hydrolyzed J. curcas seed oil can be raised from 1.89\% to 102.2\%, which proved by FTIR and HPLC.

\section{Background}

Hydrolysis of oils and fats is the applied term to the operation in which ethanolic $\mathrm{KOH}$ reacts with oil to form glycerol and fatty acids (FAs). Production of FAs and glycerol from oils are important especially in oleochemical industries. FAs and glycerol are widely used as raw materials in food, cosmetics, pharmaceutical industries [1,2], soap production, synthetic detergents, greases, cosmetics, and several other products [3].

The soap production starting from triglycerides and alkalis is accomplished for more than 2000 years by the [4]. Saponification is the alkaline hydrolysis of triacylglycerol Figure 1. These reactions produce the FAs that are the starting point for most oleochemical production. As the primary feedstocks are oils and fats, glycerol is produced as a valuable byproduct. Reaction routes and conditions with efficient glycerol recovery are required to maximize the economics of large-scale production [5].

Lipid hydrolysis is usually carried out in the laboratory by refluxing oils and fats with different catalysts [6]. The

\footnotetext{
* Correspondence: jumat@ukm.my

School of Chemical Sciences and Food Technology, Faculty of Science and Technology, Universiti Kebangsaan Malaysia, 43600 Bangi, Selangor, Malaysia
}

reaction can be catalyzed by acid, base, or lipase, but it also occurs as an un-catalyzed reaction between fats and water dissolved in the fat phase at suitable temperatures and pressures [7].

Researchers have been used several methods to prepare FAs and glycerol such as enzymatic hydrolysis using lipases from Aspergillus niger, Rhizopus javanicus and Penicillium solitum [8], C. rugosa [1], and subcritical water [3]. Nowadays, researchers have used potassium hydroxide catalyzed hydrolysis of esters is sometimes known as saponification because of its relationship with soap making. There are two big advantages of doing this. The reactions are one-way rather than reversible, and the products are easier to separate as shown in [3]. On a laboratory scale, alkaline hydrolysis is carried out with only a slight excess of alkali, typically potassium or sodium hydroxide in ethanol, refluxing for $1 \mathrm{~h}$, and the FAs recovered after acidification of the reaction mixture. This is a sufficiently mild procedure that most FAs, including polyunsaturates, epoxides, and cyclopropenes, are unaltered [9]. 


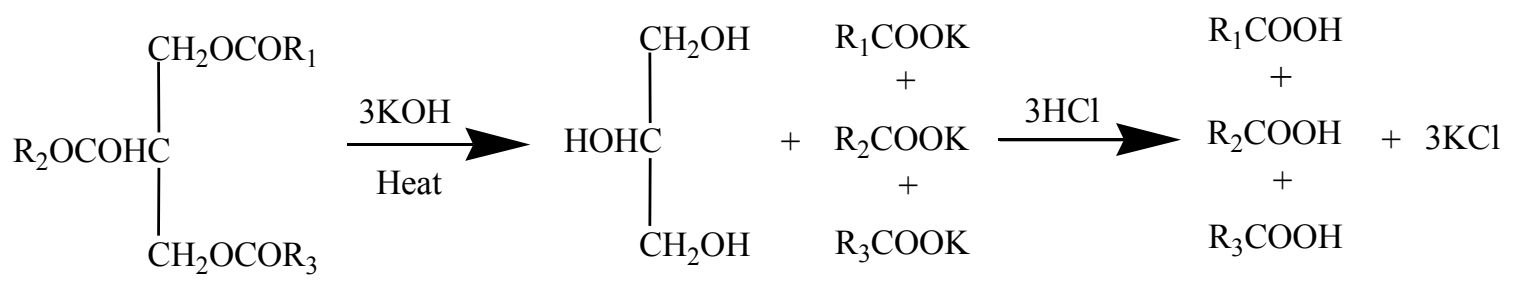

Triacylglycerol

Glycerol

Fatty Acid

Potassium

Fatty Acid Salt

Figure 1 Hydrolysis reaction of $J$. curcas seed oil.

Today ethanol is given emphasis over methanol in the world. Methanol was preferred in the seventies and eighties but the interest for methanol ended and instead ethanol programs were initialized. The grain-ethanol production, which today dominates the Europe alternative fuel market, may decide the technological path for decades to come. Today some European countries have commercial plants and pilot plant on ethanol production but no plant on methanol production [10].

Several reports have appeared on the hydrolysis of oils and fats using enzymes. Fats and oils can hydrolyze in the presence of natural enzymes. Enzyme reactions require milder conditions, less solvent, and give cleaner products attributes of green chemistry. There is increasing interest in the use of lipase enzymes for large-scale reactions. Reaction generally occurs under milder conditions of temperature and $\mathrm{pH}$ and there is reduced danger of undesirable side-reactions [6].

Though several studies which have appeared on the use of enzymes for hydrolysis of fats and oils. These studies have used to hydrolysis of FAs depends on the types of catalysts, types of vegetable oils and also depends on the different variables such as temperature and time to achieve $100 \%$ hydrolysis of vegetable oils. Hydrolysis of $J$. curcas seed oil by using sodium hydroxide $\mathrm{NaOH}$ [11] and potassium hydroxide $\mathrm{KOH}$ [12] have been studied. The literatures $[11,12]$ showed that with using methanol and $\mathrm{NaOH}$, the experiment was conducted with optimum molar ratio (6:1) keeping the catalyst concentration $(1 \% \mathrm{NaOH})$, reaction temperature $\left(65^{\circ} \mathrm{C}\right)$ and reaction time $(1 \mathrm{~h})$. But by using $\mathrm{KOH}$, the experiment was conducted with optimum molar ratio (8:1) keeping the catalyst concentration $(1 \% \mathrm{KOH})$, reaction temperature $\left(70^{\circ} \mathrm{C}\right)$ and reaction time $(31 / 2 \mathrm{~h})$.

This study is executed for the factors that affect the process of hydrolysis of J. curcas seed oil. D-optimal design was used to evaluate the effect of three factors, such as concentrations of ethanolic $\mathrm{KOH}$ concentration, temperature and time reaction were studied for the optimum hydrolysis.

\section{Results and discussion}

\section{Effect of Process Parameters and Statistical Analysis}

D-optimal design optimization was employed to study the percentage of free fatty acid (FFA\%) by ethanolic $\mathrm{KOH}$ concentration hydrolysis of $J$. curcas seed oil. Experimental results of FFA\% for the ethanolic $\mathrm{KOH}$ concentration effects to $J$. curcas seed oil hydrolysis are given in Table 1.

The results show the hydrolysis performance of the ethanolic $\mathrm{KOH}$ effects on the hydrolysis reactions when submitted to different experimental conditions. Hydrolysis reactions were carried out at various ethanolic $\mathrm{KOH}$ concentrations ranging from 1.00 to $2.00 \mathrm{M}$. Table 1 demonstrates the effect of ethanolic $\mathrm{KOH}$ concentration on the FFA\%. The FFA\% at $1.00 \mathrm{M}$ was low, however, it increased with increasing ethanolic $\mathrm{KOH}$ concentration, it can be clearly seen that the maximum FFA\% obtained at $1.75 \mathrm{M}$ was about $102.2 \%$. A different observation was reported by other researchers for hydrolysis of various vegetable using C. rugosa lipase [13-15]. Increase in enzyme concentration did not give any significant changes in the reaction rate [15].

The effect of the reaction temperature on the FFA\% is shown in Table 1. The FFA\% increased when the temperature was increased from 50 to $70^{\circ} \mathrm{C}$. At a reaction temperature of approximately $65^{\circ} \mathrm{C}$, a percentage of FFA was achieved at $102.2 \%$. This result indicates that the temperature is important factor in the hydrolysis of $J$. curcas seed oil. This theory was reported by [1] using enzyme C. rugosa lipase.

Table 1 indicates the FFA\% using different times (1.5, 2.0 and $2.5 \mathrm{~h}$ ) with different variables, such as concentration of $\mathrm{KOH}$ and reaction temperatures. The FFA\% increased with an increase in the reaction time, as shown in Table $1 ; 2.0 \mathrm{~h}$ was chosen to obtain the highest percentage of FFA (102.2\%).

The quadratic regression coefficient was obtained by employing the least squares method technique to predict quadratic polynomial models for the FFA\% $(Y)$, as shown in Table 2. 
Table 1 D-optimal design optimization of J. curcas seed oil hydrolysis and response for FFA\%.

\begin{tabular}{|c|c|c|c|c|}
\hline \multirow[t]{2}{*}{ Run no. } & \multicolumn{3}{|c|}{ Coded independent variable levels } & \multirow[t]{2}{*}{ FFA, \% (responses } \\
\hline & Ethanolic KOH $\left(\mathrm{M}, X_{1}\right)$ & Temperature $\left({ }^{\circ} \mathrm{C}, X_{2}\right)$ & Time $\left(h, X_{3}\right)$ & \\
\hline 1 & 2.00 & 50 & 1.5 & 97.1 \\
\hline 2 & 2.00 & 70 & 2.5 & 102.4 \\
\hline 3 & 1.00 & 50 & 1.5 & 53.9 \\
\hline 4 & 1.00 & 60 & 2.0 & 64.6 \\
\hline 5 & 2.00 & 50 & 2.5 & 97.5 \\
\hline 6 & 1.75 & 65 & 2.0 & 102.2 \\
\hline 7 & 2.00 & 50 & 2.5 & 99.1 \\
\hline 8 & 1.00 & 50 & 2.5 & 60.8 \\
\hline 9 & 1.00 & 70 & 2.5 & 77.1 \\
\hline 10 & 1.50 & 60 & 2.5 & 97.4 \\
\hline 11 & 1.00 & 50 & 2.5 & 67.9 \\
\hline 12 & 2.00 & 60 & 1.5 & 100.3 \\
\hline 13 & 1.00 & 50 & 1.5 & 55.1 \\
\hline 14 & 1.00 & 70 & 1.5 & 70.0 \\
\hline 15 & 1.50 & 50 & 2.0 & 96.72 \\
\hline 16 & 2.00 & 70 & 1.5 & 100.4 \\
\hline 17 & 1.00 & 70 & 2.5 & 72.4 \\
\hline 18 & 1.50 & 70 & 1.5 & 99.2 \\
\hline
\end{tabular}

Examination of these coefficients with a $T$-test shows that the FFA\% $(Y)$, linear, square and interaction terms of ethanolic $\mathrm{KOH}\left(X_{1}\right)$ were highly significant $(p<0.01)$, and that the linear terms of reaction temperature ${ }^{\circ} \mathrm{C}\left(X_{2}\right)$ were highly significant $(p<0.01)$, while the reaction time $\left(\mathrm{X}_{3}\right)$ was significant at $p<0.05$. The coefficients of independent variables (ethanolic $\mathrm{KOH}$; $X_{1}$, reaction temperature; $X_{2}$ and reaction time; $X_{3}$ ) determined for the quadratic polynomial models (Table 2 ) for the FFA\% $(Y)$ are given below:

Table 2 Regression coefficients of the predicted quadratic polynomial model for response variables $Y$ (FFA\%).

\begin{tabular}{lllll}
\hline Variables & Coefficients $(\boldsymbol{B}) \%$ FFA $(\boldsymbol{Y})$ & $\boldsymbol{T}$ & $\boldsymbol{P}$ & Notability \\
\hline Intercept & 96.65 & 144.21 & 0.0001 & $* * *$ \\
Linear & & & & \\
$X_{1}$ & 17.28 & 889.81 & 0.0001 & $* * *$ \\
$X_{2}$ & 4.33 & 57.02 & 0.0001 & $* * *$ \\
$X_{3}$ & 1.91 & 9.52 & 0.0150 & $* *$ \\
Square & & & & \\
$X_{11}$ & -15.14 & 130.05 & 0.0001 & $* * *$ \\
$X_{22}$ & 0.37 & 0.085 & 0.7777 & \\
$X_{33}$ & 0.63 & 0.33 & 0.5838 & \\
Interaction & & & & \\
$X_{12}$ & -3.48 & 30.63 & 0.0006 & $* * *$ \\
$X_{13}$ & -1.40 & 4.02 & 0.0800 & \\
$X_{23}$ & 0.11 & 0.023 & 0.8825 & \\
$R^{2}$ & 0.99 & & & \\
\hline
\end{tabular}

Notes: ${ }^{* *} P<0.05 ;{ }^{* *} P<0.01 . T$ : $F$ test value

See Table 1 for a description of the abbreviations
$Y=+96.65+17.28 X_{1}+4.33 X_{2}+1.91 X_{3}-15.14 X_{1}{ }^{2}+0.37 X_{2}{ }^{2}+0.63 X_{3}{ }^{2}-3.48 X_{1} X_{2}-1.40 X_{1} X_{3}+0.11 X_{2} X_{3}$

ANOVAs for the fitted models are summarised in Table 3. The examination of the model with an F-test and $T$-test indicate a non-significant lack-of-fit at $\mathrm{p}>$ 0.05 relative to pure error $(9.56 \%)$. The regression coefficient $\left(R^{2}\right)$ for data on the FFA\% was 0.99 (Table 2). This indicates that the generated models adequately explained the data variation and represented the actual relationships among the reaction parameters [16].

Equation (1) showed that the FFA\% have a complex relationship with independent variables that encompass both first- and second-order polynomials. RSM is one of the best ways of evaluating the relationships between responses, variables and interactions that exist [16]. Significant interaction variables in the fitted models (Table 2) were chosen as the axes (concentration of ethanolic $\mathrm{KOH} ; X_{1}$, reaction temperature; $X_{2}$ and reaction time; $X_{3}$ ) for the response surface plots. The relationships

Table 3 Analysis of variance (ANOVA) of the response $Y$ (FFA\%) of the D-optimal design

\begin{tabular}{llllll}
\hline Source & $\boldsymbol{D f}^{\mathbf{a}}$ & Sum of squares & Mean square & $\boldsymbol{F}^{\mathbf{b}}$ & $\boldsymbol{P}^{\mathbf{c}}$ \\
\hline Mean & 1 & $1.275 \mathrm{E}+005$ & $1.274 \mathrm{E}+005$ & & \\
Linear & 3 & 4921.05 & 1640.35 & 31.43 & 0.0001 \\
Square & 3 & 99.09 & 33.03 & 0.52 & 0.6756 \\
Interaction & 3 & 581.55 & 193.85 & 26.39 & 0.0002 \\
Lack-of-fit & 4 & 20.45 & 5.11 & 0.53 & 0.7205 \\
Pure error & 4 & 38.25 & 9.56 & & \\
Total & 18 & $1.330 \mathrm{E}+005$ & 7389.78 & & \\
\hline
\end{tabular}

Notes: Df: degree freedom (a); F-value: distribution (b); P-value: scale (c). 
between independent and dependent variables are shown in the three-dimensional representation as response surfaces. The response surfaces for the FFA\% $(Y)$ in the concentrates were given in Figures 2, 3 and 4.

The contour plot (Figures 2b, 3b and $4 \mathrm{~b}$ ) shows the combination of levels of the concentration of $\mathrm{KOH}$ and reaction temperature that can provide the same FFA\%. Canonical analysis was performed on the predicted quadratic polynomial models to examine the overall shape of the response surface curves and used to characterise the nature of the stationary points. Canonical analysis is a mathematical approach used to locate the

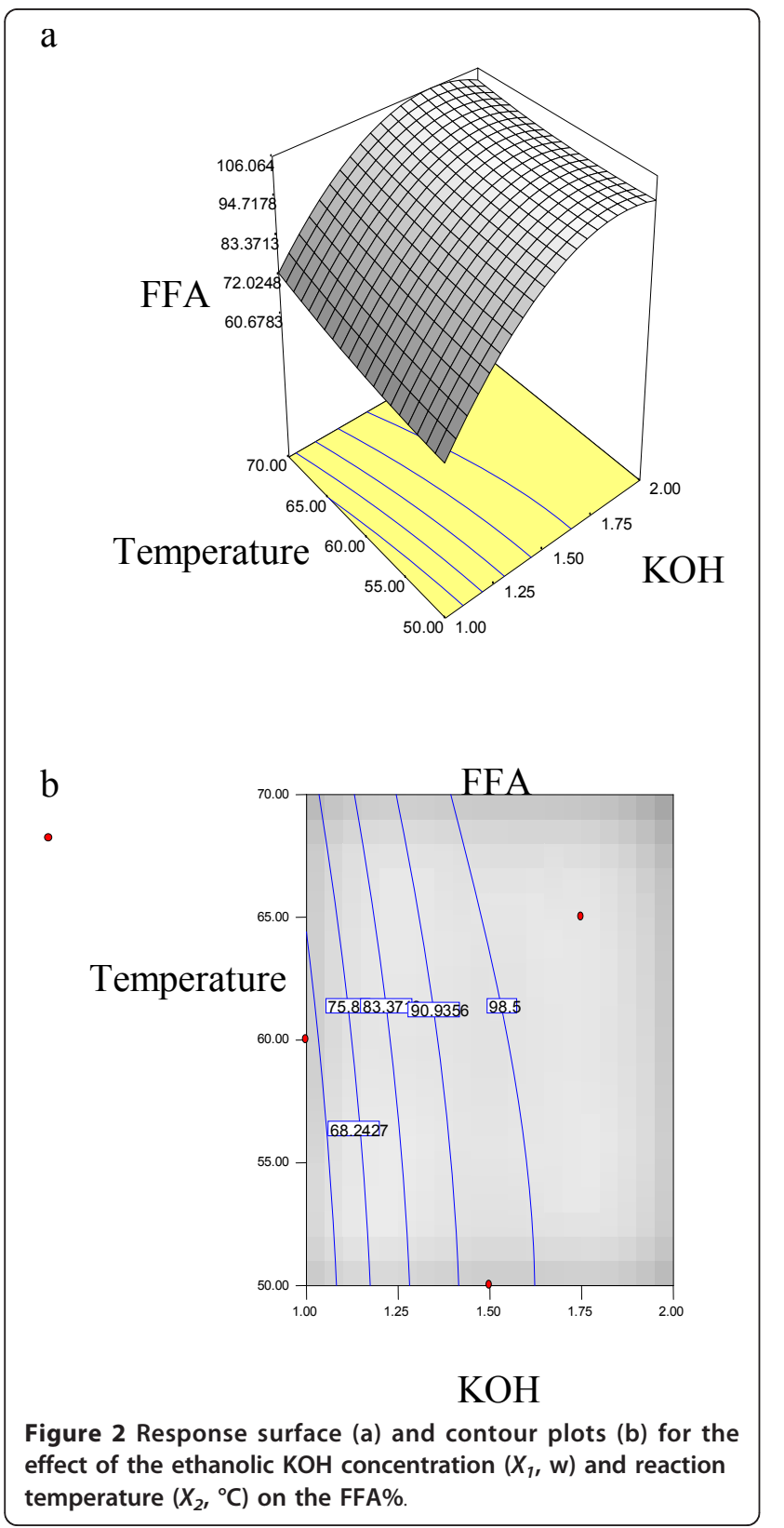

stationary point of the response surface and to determine whether it represents a maximum, minimum or saddle point $[16,17]$. Ethanolic $\mathrm{KOH}$ concentration was the most important factor for FFA\%, which the observed value was reasonably close to the predicted value as shown in Figure 5.

\section{GC-FID Analysis of Fatty Acids Composition}

Response surface methodology (RSM) was employed to study the composition of FFA by ethanolic $\mathrm{KOH}$ concentration of $J$. curcas seed oil hydrolysis through FAMEs analysis before and after the hydrolysis. The analyses made by GC-FID had a positive identification

$\mathrm{a}$

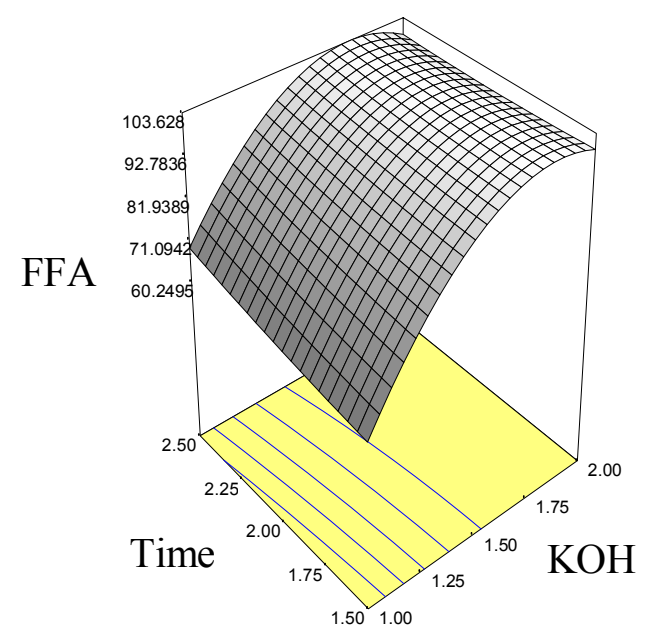

b

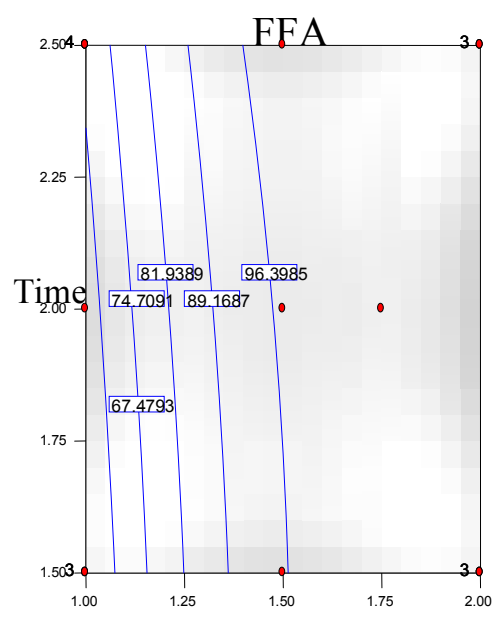

$\mathrm{KOH}$

Figure 3 Response surface (a) and contour plots (b) for the effect of the ethanolic $\mathrm{KOH}$ concentration $\left(X_{1}, \mathrm{w}\right)$ and reaction time $\left(X_{3}, h\right)$ on the FFA\%. 


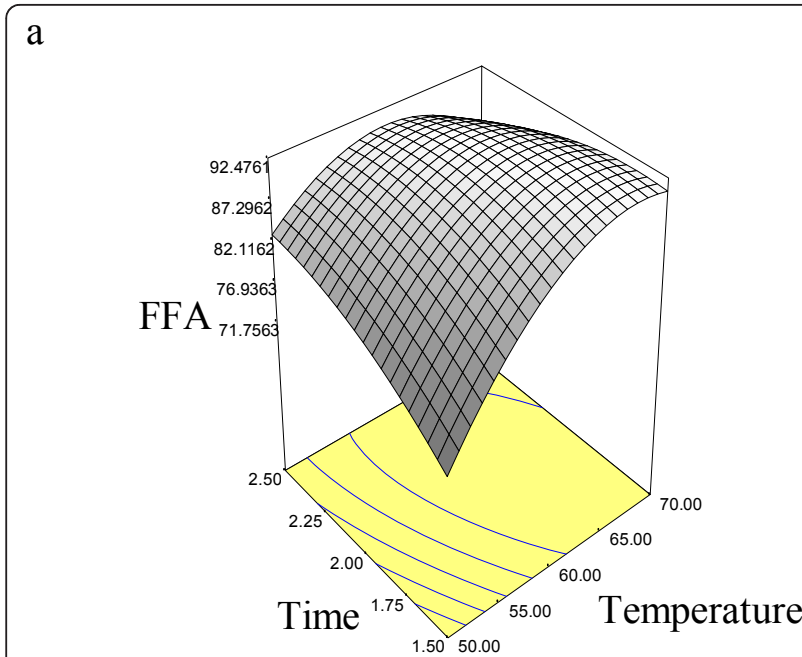

b

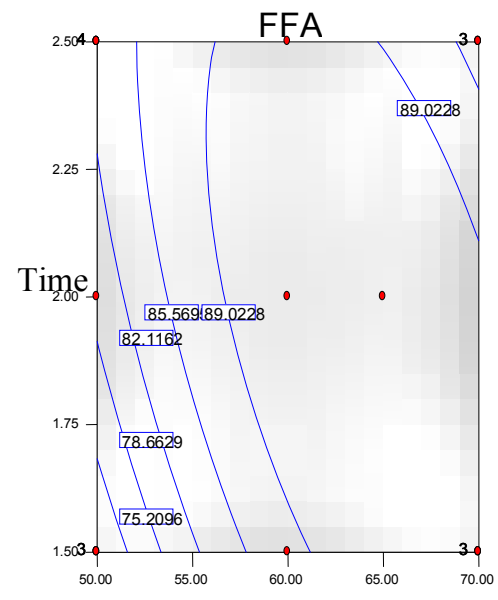

Temperature

Figure 4 Response surface (a) and contour plots (b) for the effect of the reaction temperature $\left(X_{2},{ }^{\circ} \mathrm{C}\right)$ and reaction time $\left(X_{3}, \mathrm{~h}\right)$ on the FFA\%.

of FAs. Experimental results of the percentage of the composition of FAs for ethanolic $\mathrm{KOH}$ reactions with $J$. curcas seed oil are given in Table 4. The comparative data indicate that no significant difference under the optimum conditions $p<0.05$.

Table 4 shows a comparison of the FAs composition before the hydrolysis (a) and after the hydrolysis at different ethanolic $\mathrm{KOH}$ concentration (b and c, respectively), as determined directly by GC-FID, through FAMEs analysis. Intermediate products formed in the hydrolysis, as well as the methyl esters by FAMEs [3].

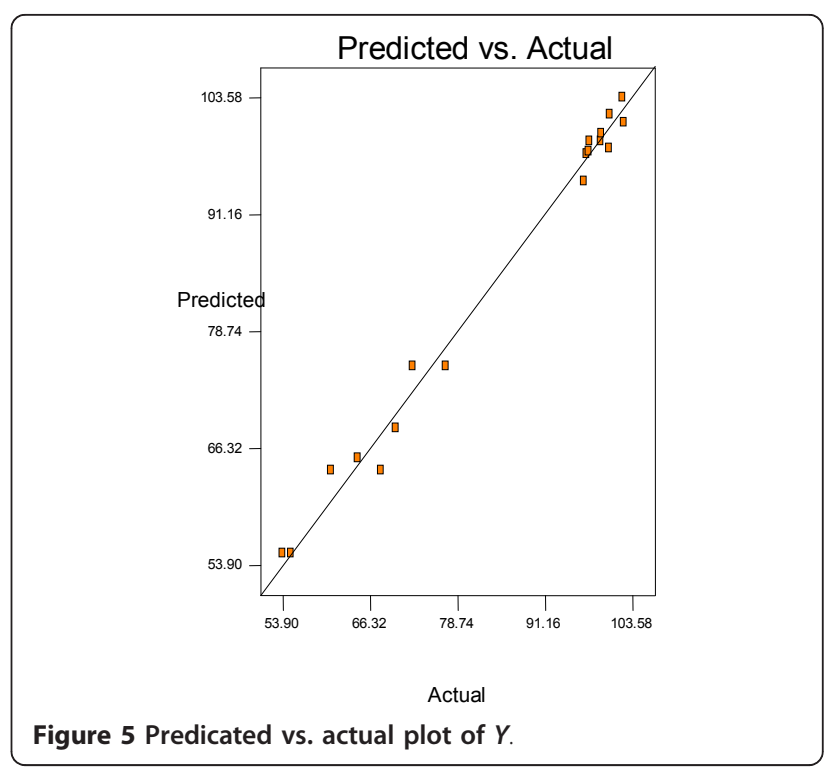

The comparative data indicate that the hydrolysis does not cause the decomposition of the FAs.

\section{FTIR Analysis of Fatty Acids}

In order to prove the J. curcas seed oil hydrolysis, FTIR spectroscopy supported the FFA\% by showing the main peaks and their functional groups of the J. curcas seed oil. The comparison between J. curcas seed oil (a), hydrolysis at $1.00 \mathrm{M} \mathrm{(b)} \mathrm{and} \mathrm{at} 1.75 \mathrm{M}$ of ethanolic $\mathrm{KOH}$ concentration (c), FTIR spectra is shown in Figure 6. The main peaks and their assignment to functional groups are given in Table 5 .

For carboxylic acid carbonyl functional groups $(\mathrm{C}=$ O), FTIR spectrum showed absorption bands of hydrolysis oil (b and c) at $1711 \mathrm{~cm}^{-1}$ for stretching vibration, $1283-1285 \mathrm{~cm}^{-1}$ for stretching asymmetric while at 1413 and $918-937 \mathrm{~cm}^{-1}$ for bending vibration of carboxylic acid [18]. The hydrolysis of J. curcas seed oil at $1.75 \mathrm{M}$ show disappeared completely of ester groups at 1746 and $1163 \mathrm{~cm}^{-1}$.

Figure 6 show the main change of hydrolysis J. curcas seed oil (b and c), which (b) $1.00 \mathrm{M}$ ethanolic $\mathrm{KOH}$ solution show low hydrolysis with $\mathrm{C}=\mathrm{O}$ (ester carbonyl) at $1739,1180 \mathrm{~cm}^{-1}$ while (c) at $1.75 \mathrm{M}$ ethanolic $\mathrm{KOH}$ solution shows high hydrolysis with strong absorption. Peaks at 2925- $2854 \mathrm{~cm}^{-1}$ indicated the $\mathrm{CH}_{2}$ and $\mathrm{CH}_{3}$ scissoring of both J. curcas seed oil and hydrolysis oil which showed on Figure 6(a), (b) and 6(c). FTIR spectrum also showed absorption bands at $722 \mathrm{~cm}^{-1}$ for $(\mathrm{C}-\mathrm{H})$ group vibration.

\section{HPLC Analysis of Fatty Acids}

The results by using higher performance liquid chromatography (HPLC) show the hydrolysis performances of 
Table 4 Fatty acid composition before and after J. curcas seed oil hydrolysis

\begin{tabular}{lcccc}
\hline Fatty acids & FA\% before hydrolysis $^{\mathbf{a}}$ & FA\% after hydrolysis $^{\mathbf{1 . 0 0} \mathbf{M}^{\mathbf{b}}}$ & FA\% after hydrolysis $^{\mathbf{1 . 5 0} \mathbf{M M}^{\mathbf{c}}}$ & FA\% after hydrolysis $^{\mathbf{1 . 7 5} \mathbf{M}^{\mathbf{d}}}$ \\
\hline Palmitic & 13.19 & 13.55 & 13.06 & 13.07 \\
Palmitoleic & 0.40 & 0.64 & 0.56 & 0.55 \\
Stearic & 6.36 & 4.52 & 6.78 & 6.80 \\
Oleic & 43.32 & 43.94 & 43.97 & 43.03 \\
Linoleic & 36.70 & 37.32 & 36.46 & 36.51 \\
\hline
\end{tabular}

Notes: J. curcas seed oil (a), hydrolysis at $70^{\circ} \mathrm{C}$ (b), (c) and (d)

the ethanolic $\mathrm{KOH}$ concentration effects on the hydrolysis reaction when submitted to different concentrations of the ethanolic $\mathrm{KOH}(1.0,1.5$ and $1.75 \mathrm{M})$. The study of variation yield of the hydrolysis $J$. curcas seed oil has been showed in Figures 7, 8, 9 and 10.

Figure 7 illustrates a typical profile of triacylglycerol obtained of non hydrolyzed J. curcas seed oil. Figures 8, 9 and 10 illustrate the variation of the chromatographic profile of hydrolyzed $J$. curcas seed oil as a function of the ethanolic $\mathrm{KOH}$ concentration effects at 1.00, 1.50 and $1.75 \mathrm{M}$, respectively.

HPLC chromatogram results showed, that with increasing ethanolic $\mathrm{KOH}$ concentration an increase in the FFA\% and decreases of the concentration of the triacylglycerol is observed, fact that supports the hydrolysis model under investigation. A different observation was reported by other researchers for hydrolysis of various vegetable using $C$. rugosa lipase [13-15]. Increase in enzyme concentration did not give any significant changes in the reaction rate [15]. Therefore, further increase in ethanolic $\mathrm{KOH}$ solution concentration show improvement in the conversion.

\section{Experimental}

\section{Procedure of J. curcas Seed Oil Hydrolysis}

FFA was obtained by the hydrolysis of J. curcas seed oil, as carried out by [19]. Table 6 shows different ethanolic $\mathrm{KOH}$ concentration, different reaction temperature and

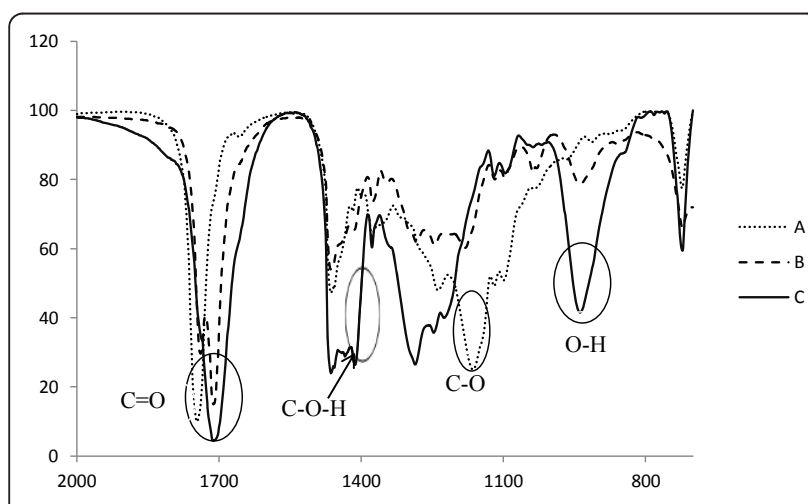

Figure 6 FTIR spectrum of $J$. curcas seed oil (a) hydrolysis at 1.00 $\mathrm{M}$ of ethanolic $\mathrm{KOH}$ (b) hydrolysis at $1.75 \mathrm{M}$ of ethanolic $\mathrm{KOH}$ (c). different reaction time using RSM (D-optimal design). Factors such as ethanolic $\mathrm{KOH}$ concentration $\left(\mathrm{M}, X_{1}\right)$, temperature $\left({ }^{\circ} \mathrm{C}, X_{2}\right)$ and time $\left(\mathrm{h}, X_{3}\right)$ were performed under the same experimental conditions. In a typical experiment, $J$. curcas seed oil $50 \mathrm{~g}$ was mixed in the reactor with $300 \mathrm{~mL}$ of saponifying solution comprising of ethanolic $\mathrm{KOH}$ concentration (1.00-2.00 M), and ethanol (300 mL: 90\% v/v). The hydrolysis was carried out in a $500 \mathrm{~mL}$ temperature-controlled reactor at different reaction temperature $50-70^{\circ} \mathrm{C}$ and different reaction time $1.5-2.5 \mathrm{~h}$ as shown in Table 6 . After the hydrolysis, $200 \mathrm{~mL}$ water was added to the mixture. Unsaponifiables were separated by extraction with 100 $\mathrm{mL}$ of hexane. The aqueous alcohol phase, containing the soaps, was acidified to $\mathrm{pH} 1$ with $\mathrm{HCl} 6 \mathrm{~N}$, and the FFA was recovered by extraction with hexane. The extract was washed with distilled water to neutral $\mathrm{pH}$. The resulting lower layer was removed using a separating funnel and discarded. The FFA-containing upper layer was dried with anhydrous magnesium sulfate, and solvent was evaporated in a vacuum rotary evaporator at $35^{\circ} \mathrm{C}$. The FFA\% was measured.

\section{Determination of the FFA\%}

The FFA\% of the hydrolysis of J. curcas seed oil was determined according to [20]. Approximately $50 \mathrm{~mL}$ of isopropanol was placed into the flask, and about $0.5 \mathrm{~mL}$ phenolphthalein was added and was neutralised by addition of sodium hydroxide $(\mathrm{NaOH}, 0.02 \mathrm{~N})$ until a permanent pink colour was obtained. The neutralised isopropanol was added to the $5 \mathrm{~g}$ of FFA, which was placed into an Erlenmeyer flask, and about $0.5 \mathrm{~mL}$ of phenolphthalein was added. After shaking the mixture gently, the mixture was neutralised by the addition of $(\mathrm{NaOH}, 0.02 \mathrm{~N})$ until the first permanent pink colour was obtained. The FFA\% was calculated by using equation 2 .

$$
\% \text { FFA as oleic }=\frac{28.2 \times \mathrm{N} \times \mathrm{V}}{\mathrm{W}}
$$

\section{Gas Chromatography Method Analysis of Fatty Acids Composition}

Gas chromatography method (GC) analysis was performed on Shimadzu equipped with flame ionization 
Table 5 The main wavelengths in the FTIR functional groups of J. curcas seed oil hydrolysis

\begin{tabular}{|c|c|c|c|}
\hline Wavelength of oil ${ }^{\mathrm{a}}$ & Wavelength of $1.00 \mathrm{M}^{\mathrm{b}}$ & Wavelength of $1.75 \mathrm{M}^{\mathrm{c}}$ & Functional group \\
\hline 3009 & 3009 & 3009 & $\mathrm{C}=\mathrm{C}$ bending vibration (aliphatic) \\
\hline 2927,2855 & 2925,2854 & 2924,2854 & C-H stretching vibration (aliphatic) \\
\hline 1746 & 1739 & - & $\mathrm{C}=\mathrm{O}$ stretching vibration (ester) \\
\hline- & 1711 & 1711 & $\mathrm{C}=\mathrm{O}$ stretching vibration (carboxylic acid) \\
\hline 1463 & 1464 & 1463 & $\mathrm{C}-\mathrm{H}$ scissoring and bending for methylene \\
\hline- & 1283 & 1285 & C-O stretching asymmetric (carboxylic acid) \\
\hline 1163 & 1180 & - & C-O bending vibration (ester) \\
\hline- & 937 & 918 & O-H bending vibration (carboxylic acid) \\
\hline 722 & 722 & 722 & C-H group vibration (aliphatic) \\
\hline
\end{tabular}

Notes: J. curcas seed oil (a), hydrolysis at $1.00 \mathrm{M}$ of ethanolic $\mathrm{KOH}$ (b), hydrolysis at $1.75 \mathrm{M}$ of ethanolic $\mathrm{KOH}$ (c).

detector and capillary column $(30 \mathrm{~m} \times 0.25 \mathrm{~mm} \times 0.25$ $\mathrm{mm}$ film). The parameters of GC have been carried out according to [21].

\section{Fourier Transforms Infrared Spectroscopy analysis of Fatty Acids}

Fourier transforms infrared spectroscopy (FTIR) has been carried out according to [21]. FTIR of the products was recorded on a Perkin Elmer Spectrum GX spectrophotometer in the range $400-4000 \mathrm{~cm}^{-1}$. FTIR was used to measure functional groups of FA. A very thin film of FA was covered on $\mathrm{NaCl}$ cells $(25$ mmi.d $\times 4$ mm thickness) and was used for analysis.

\section{High Performance Liquid Chromatography Method Analysis of fatty Acids}

High performance liquid chromatography (HPLC) was performed on waters model 1515 equipped with refractive index detector and Spherisorb C18 column (250 $\mathrm{mm} \times 4.8 \mathrm{~mm} \times 3 \mathrm{~mm}$ ) was used for analysis the TAG, DAG, MAG and FFA. The parameters of HPLC have been carried out according to [21]. The samples were

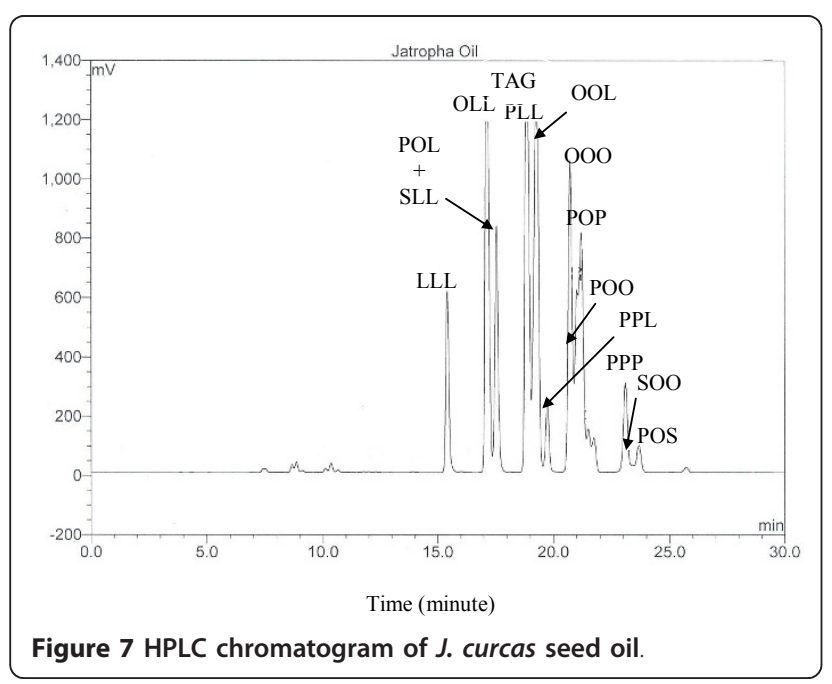

dissolved in $10 \mathrm{~mL}$ of the mixture acetone: acetonitrile before $20 \mathrm{~mL}$ of the sample inject into HPLC.

\section{Experimental Design (D-Optimal) and Statistical Analysis}

A three-factor D-optimal design was employed to study the responses of FFA\% [ $Y$ in \% by wt, see Eq. (2)]. An initial screening step was carried out to select the major response factors and their values. The independent variables were $X_{1}, X_{2}$ and $X_{3}$ representing the concentration of ethanolic $\mathrm{KOH}(\mathrm{M})$, reaction temperature $\left({ }^{\circ} \mathrm{C}\right)$, and reaction time $(\mathrm{h})$, respectively. The settings for the independent variables were as follows (low and high values): $\mathrm{KOH}$ concentration of 1.00 and $2.00 \mathrm{M}$; hydrolysis temperature of 50 and $70^{\circ} \mathrm{C}$; and hydrolysis time of 1.5 and $2.5 \mathrm{~h}$. Each variable to be optimized was coded at three levels: $-1,0$, and +1 . Six replicates the D-optimal design is shown in Table 6. A quadratic polynomial regression model was assumed for predicting individual $Y$ variables. The model proposed for each response of $Y$ was:

$$
Y=\beta_{0}+\sum \beta_{i} x_{i}+\sum \beta_{i i} x_{i}^{2}+\sum \sum \beta_{i j} x_{i} x_{j}
$$

Where $\beta_{O} ; \beta_{i} ; \beta_{i i}$ and $\beta_{i j}$ are constant, linear, square and interaction regression coefficient terms, respectively, and $x i$ and $x j$ are independent variables. The Minitab software version 14 (Minitab Inc., USA) was used for

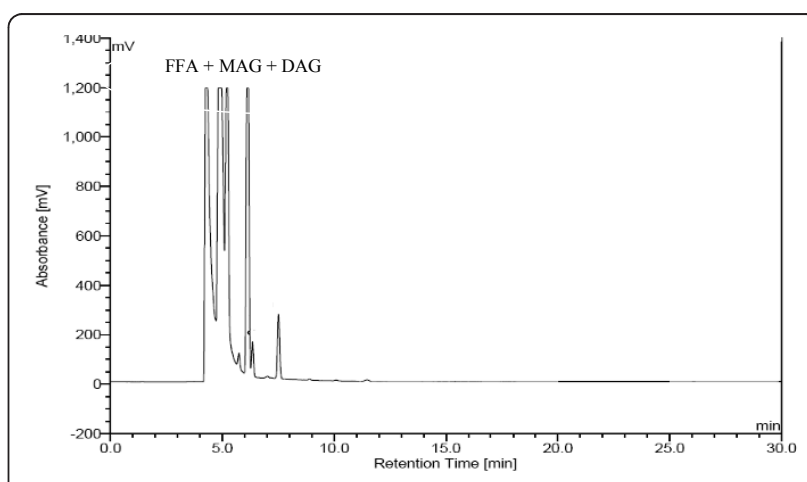

Figure 8 HPLC chromatogram after hydrolysis of J. curcas seed oil with ethanolic $\mathrm{KOH}$ at $1.00 \mathrm{M}$ 


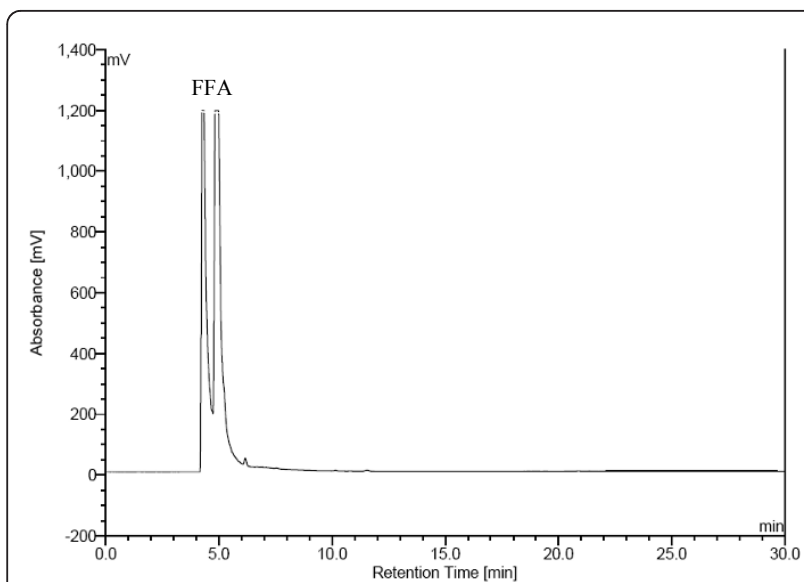

Figure 9 HPLC chromatogram after hydrolysis of $J$. curcas seed oil with ethanolic $\mathrm{KOH}$ at $1.5 \mathrm{M}$.

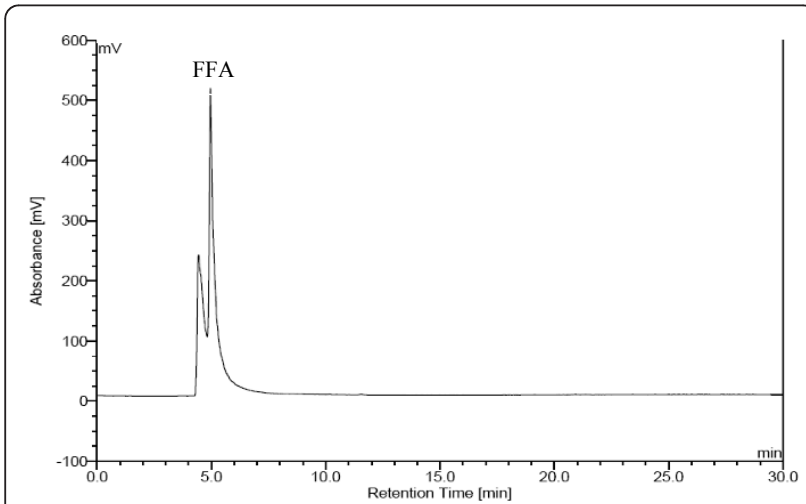

Figure $10 \mathrm{HPLC}$ chromatogram after hydrolysis of $J$. curcas seed oil with ethanolic $\mathrm{KOH}$ at $1.75 \mathrm{M}$

Table 6 Independent variables and their levels for Doptimal design of the hydrolysis reaction

\begin{tabular}{ccccc}
\hline Independent variables & & \multicolumn{3}{c}{ Variable levels } \\
& & -1 & 0 & 1 \\
\hline $\mathrm{KOH}(\mathrm{M})$ & $X_{1}$ & 1 & 1.5 & 2 \\
Temperature $\left({ }^{\circ} \mathrm{C}\right)$ & $X_{2}$ & 50 & 60 & 70 \\
Time $(\mathrm{h})$ & $X_{3}$ & 1.5 & 2 & 2.5 \\
\hline
\end{tabular}

multiple regression analysis, analysis of variance (ANOVA), and analysis of ridge maximum of data in the response surface regression (RSREG) procedure. The goodness of fit of the model was evaluated by the coefficient of determination $R^{2}$ and the analysis of variance (ANOVA) [16].

\section{Conclusion}

J. curcas seed oil hydrolysis, under optimum conditions, a highest hydrolysis was achieved. Hydrolysis occurs rapidly at $1.75 \mathrm{M}$ of ethanolic $\mathrm{KOH}$, yielding $102.2 \%$ of the FFA. The analyses made by GC-FID had a positive identification of FAs composition and there is no significant difference under the optimum conditions $p<0.05$. FTIR analyses showed strong absorption of carboxylic acid peaks at 1711 and $1285 \mathrm{~cm}^{-1}$. The results by using HPLC showed with increasing in ethanolic $\mathrm{KOH}$ concentration shows improvement in the J. curcas seed oil hydrolysis.

\section{Acknowledgements}

We would like to thank UKM and the Ministry of Science and Technology for research grant UKM-GUP-NBT-08-27-113 and UKM-OUP-NBT-29-150/2011.

\section{Authors' contributions}

JS developed the concept, analyzed the data and drafted the manuscript. BMA performed the hydrolysis reaction optimization and its characterization study. NS advised on the methods of tests. All authors read and approved the final manuscript.

\section{Competing interests}

The authors declare that they have no competing interests.

Received: 1 August 2011 Accepted: 1 November 2011

Published: 1 November 2011

\section{References}

1. Serri NA, Kamarudin AH, Abdul Rahaman SN: Preliminary studies for production of fatty acids from hydrolysis of cooking palm oil using $C$. rugosa lipase. Journal of physical science 2008, 19:79-88.

2. Hermansyah H, Kubo M, Shibasaki-Kitakawa N, Yonemoto T: Mathematical model for stepwise hydrolysis of triolein using Candida rugosa lipase in biphasic oil-water system. Biochemical Engineering Journal 2006, 31:125-132.

3. Pinto JSS, Lanças FM: Hydrolysis of corn oil using subcritical water. Journal of the Brazilian Chemical Society 2006, 17:85-89.

4. Ackelsberg OJ: Fat splitting. Journal of the American Oil Chemists' Society 1958, 35:635-640.

5. Scrimgeour C: Chemistry of fatty acid. In Bailey's industrial oil and fat products. Volume 5.. 6 edition. Edited by: Shahidi F. Wiley, Hoboken; 2005:1-43.

6. Gunstone FD: The chemistry of oils and fats: sources, composition, properties, and uses Blackwell publishing Ltd. CRC Press, Oxford, UK; 2004.

7. Rukmini A, Raharjo S: Pattern of Peroxide Value Changes in Virgin Coconut Oil (VCO) Due to Photo-Oxidation Sensitized by Chlorophyll. Journal of the American Oil Chemists' Society 2010, 87:1407-1412.

8. Carvalho PDO, Campos PRB, Noffs MD, Fregolente PBL, Fregolente LV: Enzymatic hydrolysis of salmon oil by native lipases: optimization of process parameters. Journal of the Brazilian Chemical Society 2009, 20:117-124.

9. Christie WW: Lipid Analysis. 3 edition. The Oily Press, Bridgwater, UK; 2002.

10. Grahn M: Why is ethanol given emphasis over methanol in Sweden? Energy, Environment and sustainability Chalmers University of Technology, course paper on the Ph.D-course. Gothenburg, Sweden; 2004.

11. Kywe T, Oo MM: Production of biodiesel from Jatropha oil (Jatropha curcas) in pilot plant. Proceeding of World Academy of Science and Technology 2009, 38:481-487.

12. Berchmans HJ, Hirata S: Biodiesel production from crude Jatropha curcas L. seed oil with a high content of free fatty acids. Bioresource Technology 2008, 99:1716-1721.

13. Noor IM, Hasan M, Ramachandran KB: Effect of operating variable on the hydrolysis rate of palm oil by lipase. Process Biochemistry 2003, 39:13-20.

14. Fadiloğlu S, Söylemez Z: Olive oil hydrolysis by celite-immobilized Candida rugosa lipase. Journal of Agriculture and Food Chemistry 1998, 46:3411-3414.

15. Rooney $D$, Weatherly $L R$ : The effect of reaction conditions upon lipase catalysed hydrolysis of high oleate sunflower oil in a stirred liquid-liquid reactor. Process Biochemistry 2001, 36:947-953. 
16. Wu M, Ding H, Wang S, Xu SH: Optimization conditions for the purification of linoleic acid from sunflower oil by urea complex fractionation. Journal of the American Oil Chemists' Society 2008, 85:677-684.

17. Mason RL, Gunst RF, Hess JL: Statistical design and analysis of experiments with applications to engineering and science Wiley, New York; 1989.

18. Socrates G: Infrared and Raman characteristic group frequencies: Tables and charts. 3 edition. John Wily \& Sons Ltd. Chichester, England; 2001.

19. Hashim HB, Salimon J: Kajian pengoptimuman tindak balas hidrolisis minyak kacang soya. The Malaysian Journal of Analytical Sciences 2008, 12:205-209.

20. AOCS: Official Methods of Analysis. Association of Official Analytical Chemist, Arlington, Cd 9F93.20; 161997.

21. Salimon J, Abdullah BM: A study on the thermal properties and solid fat content of Malaysian rubber seed oil. The Malaysian Journal of Analytical Sciences 2009, 13:1-7.

\section{doi:10.1186/1752-153X-5-67}

Cite this article as: Salimon et al:: Hydrolysis optimization and

characterization study of preparing fatty acids from Jatropha curcas

seed oil. Chemistry Central Journal 2011 5:67.

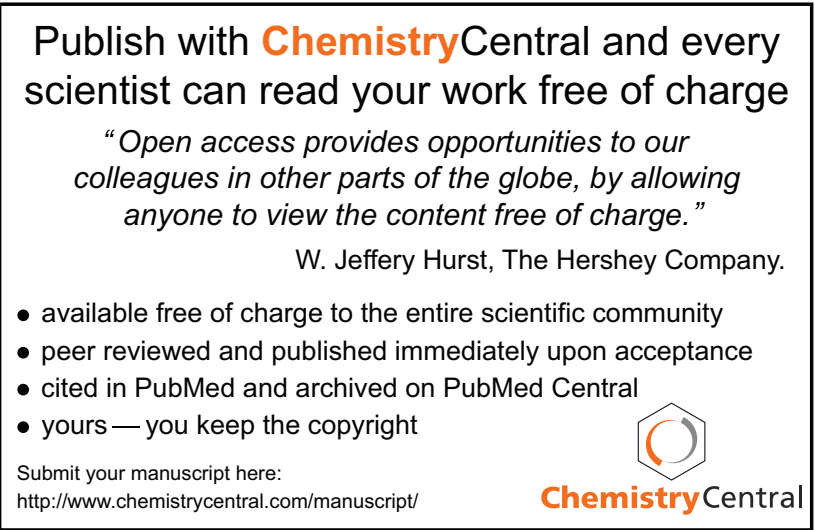

